\title{
Science-to-conservation disconnections in Borneo and British Columbia
}

\author{
by F.E. "Jack" Putz1
}

\begin{abstract}
Borneo differs fundamentally from Canada, but reflections on the struggles to improve the fates of its tropical rain forests may resonate with people engaged in the same struggles on the other side of the Pacific. I frame these reflections around the question of why my efforts as a researcher in Borneo failed to cause a change from predatory logging of old growth to conservation through improved forest management. Perhaps my most fundamental mistake was unwillingness to recognize the immense profitability of forest liquidation through multiple-premature re-entry logging, especially when followed by conversion to plantations of African oil palm or Australian acacias. Superimposed on the high opportunity costs of conservation were governance failures that diminished the effectiveness of policies set by government as well as those set by certifiers of responsible management. Conservation of the mostly remote, flooded, and steep hinterlands still covered by forest will benefit from acknowledgment of the internationally recognized intrinsic land rights of Borneo's indigenous peoples combined with full economic cost accounting of the consequences of forest degradation and conversion. Given the global importance of old growth in Borneo, Canada, and elsewhere, global funding for conservation should be made available with safeguards such as UNESCO Biosphere designations.
\end{abstract}

Keywords: failure of research to have impacts, natural forest management, old-growth, primary forest, reduced-impact logging, sustainable forest management

\section{RÉSUMÉ}

Bornéo est à tout compte fait totalement différent du Canada, mais les observations tirées des combats pour assurer la pérennité de ses forêts tropicales peuvent éveiller des échos chez les personnes impliquées dans les mêmes combats de l'autre côté du Pacifique. J'ai recadré ces observations face à la question que je soulevais à savoir pourquoi mes efforts en tant que chercheur sur place à Bornéo n'ont pas pu empêcher de transformer l'exploitation illégale des forêts anciennes en un mode de conservation découlant d'un aménagement forestier accru. Fort probablement que ma plus grande erreur fondamentale a été ma réticence à reconnaitre le niveau élevé de profitabilité issus de la liquidation des forêts à la suite d'une série d'extractions hâtives, surtout dans le cas où s'en suit la conversion des forêts en plantations de palmier à huile africain ou d'acacias australien. À cela, il faut ajouter les coûts d'opportunité élevés reliés à la conservation là où les échecs des autorités diminuent l'efficacité des politiques mises en place par le gouvernement, ainsi que celles établies par les agences de certification de l'aménagement forestier responsable. La conservation des forêts la plupart du temps retrouvées dans les zones inondées et escarpées de l'arrière-pays bénéficiera des droits intrinsèques des nations indigènes de Bornéo reconnus par l'ensemble des nations, en plus de la comptabilisation complète des coûts économiques découlant de la dégradation et de la conversion des forêts. Étant donné l'importance mondiale des forêts anciennes à Bornéo, au Canada et ailleurs dans le monde, le financement international de la conservation devrait être accessible selon des balises établies telles les désignations de la biosphère de l'UNESCO.

Mots clés : absence de recherche sur les impacts, aménagement des forêts naturelles, forêt ancienne, forêt primaire, exploitation forestière à impact réduit, aménagement forestier durable

\footnotetext{
${ }^{1}$ Department of Biology, University of Florida, Gainesville, FL 32611-8526, USA; e-mail: fep@ufl.edu
} 


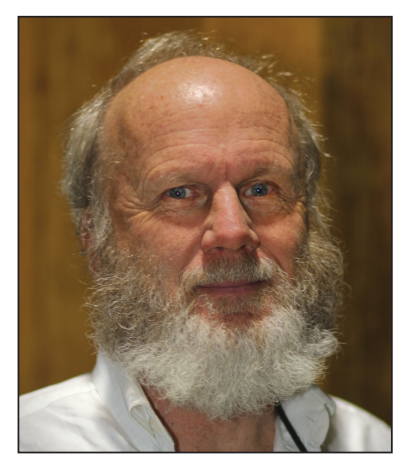

F.E. "Jack" Putz

\section{Introduction}

The thrill of being invited to present the Doug Little Memorial Lecture at the University of Northern British Columbia quickly gave way to concern about what topic to address. Given that I've spent less than a month north of the $49^{\text {th }}$ Parallel, I hesitated to say anything about Canadian forests and forestry. Furthermore, my reading about Canadian forestry is heavily biased towards studies of close-to-nature silviculture by authors such as David Coates, Phil Burton, Ian Thompson, and Christian Messier. It therefore seemed appropriate to focus my lecture and this essay on a part of the world about which I am better informed, the mega-island of Borneo (but see Putz 2018). Those tropical forests are far from Prince George and points north, but at least a few of the impediments to sustainable forest management in Borneo may resonate with researchers and others engaged in similar struggles to improve the fates of forests in British Columbia and elsewhere in Canada.

While issuing caveats about my capacity, I should clarify that, despite having spent many years in Borneo and even more time thinking, reading, and writing about that much storied island (e.g., Moro 2019), I make no claims of profound understanding. Linguistic proficiency aside, I often misunderstand what is said due to cultural nuances about which I remain unaware. Even more fundamentally, I also cannot claim to have effectively improved the fates of forests in the region; since 1973, when I commenced my researchbased conservation campaign, Borneo lost much of its lowland forest (e.g., Gaveau et al. 2018; Hughes 2018). What forest remains is mostly steep, flooded, and/or remote.

My research on ways to improve forestry practices is widely cited, but there is scant evidence that the improvements in selective logging and benefits of post-harvest silvicultural treatments about which I published were applied outside of research plots (e.g., Griscom et al. 2019). Worse yet, many logged-over forests are devoid of wildlife due to poaching for the bushmeat and pet trades. Meanwhile, both forest degradation and deforestation are facilitated by massive road-building efforts that fragment forests and, by improving access, increase the profitability of non-forest land uses. Finally, with the increased frequency and intensity of droughts associated with global climate change, the usually lush forests of Borneo are increasingly susceptible to fires that are especially devastating after rounds of exploitative logging. In writing this essay, my hope is that revelation of some reasons why my efforts as a scientist failed to improve the fates of Borneo's forests will help other conservation-minded forest researchers avoid making the same mistakes.

\section{Background}

Borneo is divided politically into the five Kalimantan Provinces of Indonesia, the Malaysian states of Sarawak and Sabah, and the oil-rich Sultanate of Brunei. Much of the island is also claimed by "First Nations" people, known col- lectively as "Dayaks" in Indonesia and "Orang Asli" in Malaysia. To this cultural, linguistic, and religious mélange should be added the mostly Muslim colonists from Peninsular Malaysia and the more populous Indonesian islands, especially Java. Prior to the 1970s, interior Borneo was mostly roadless and accessible only by the many rivers that drain this wet equatorial island. At that time, Borneo was also forested, with extensive peat swamps and various sorts of tropical forest that carpeted the rolling terrain of the lowlands to the mountainous interior, now referred to as the Heart of Borneo.

In their natural state, Bornean forests are staggeringly diverse: a single hectare can support more tree species than found in all of Canada, as well as creatures from orangutans and gibbons, to flying lemurs, flying lizards, pangolins, and rhinos. Given the lack of markets for timber from the overwhelming majority of tree species, logging is selective; typical harvests are of only 5-10 trees/ha $\left(30-80 \mathrm{~m}^{3} / \mathrm{ha}\right)$ and are sustainable with cutting cycles of 40-60 years (e.g., Ruslandi et al. 2017). Unfortunately, to maximize short-term profits, loggers typically harvest much more frequently, often with governmental approval, and almost never apply the recommended post-logging silvicultural treatments (e.g., liberation of future crop trees; Ruslandi et al. 2017). Much of the harvested wood, mostly from trees in the species-rich family Dipterocarpaceae, is sold for utility-grade plywood, not for high-value furniture or cabinetry. Selective logging does not directly cause deforestation, but revenue from timber harvests helps fund forest conversion while logging roads provide access to poachers of timber and wildlife as well as to agricultural colonists and miners.

When Indonesia became an independent nation in 1945, the government claimed all the land. Constitutional provisions were made for "traditional" owners, but restoring ownership to the indigenous peoples of the "outer" islands (i.e., any of the thousands of islands in the archipelago nation other than Java, Bali, and Madura) has only recently made any headway. In places like Borneo, little regard was paid to these traditional owners in the early 1970s when the land was partitioned up and granted as forestry concessions, mostly to political cronies and powerful members of the military. For a decade or so, forestry companies from Europe and North America ran some of the larger and more lucrative concessions, but they were squeezed out and replaced by Indonesian firms owned and operated by newcomers to Borneo, not by local indigenous people.

When there was still accessible primary lowland forest to harvest, logging profits were exorbitant due to high yields, low taxes/royalties, and Codes of Practice that were sound but seldom enforced. Widespread governance failures allowed forests to be quickly depleted of their timber by repeated re-entry logging at intervals that reflected potential profits, not rates of volume recovery. Timber revenues were then often used to defray the costs of clearing the remaining trees. The big driver of deforestation in Borneo, after the rubber boom of the 1950s-70s, became and remains the development of plantations of African oil palm (Elaeis guineensis Jacq.) with a smaller portion converted to fiber farms of Australian acacias (mostly Acacia mangium Willd.). In contrast to many boreal forests for which there are few alternative land uses other than forestry, to the opportunity costs of not 
logging in Borneo must be added the even larger costs of not converting forests into high-yielding plantations. Another difference is that in Borneo, once logging roads penetrate primary forest and concessionaires selectively log once, other loggers with lower capital investments, many without proper permits, continue to degrade what could be timber-regenerating stands.

Logging and the plantation agriculture that followed in its wake both contributed to meteoric economic growth in both Malaysia and Indonesia. While forests fell, access to health care and education improved, life expectancies increased, and more than half of their burgeoning populations became urbanites. The physical benefits of development were not equally shared, but in what only a few decades back were remote hinterlands in Borneo, many people now suffer from spotty cellphone coverage, slow internet speeds, and traffic jams.

\section{Why my conservation efforts in Borneo went wrong}

Like many idealistic environmentalists, my vision of Borneo was one of extensive forests under strict conservation or sustainable management. That vision was clearly not shared by the people who determined the fates of those forests. More realistically, I should have recognized that the opportunity costs of forest retention are simply too high to expect most of the forest to remain standing. I only became convinced of this sad reality fairly recently during a discussion with an Indonesian economist. She asked whether I would understand the pressure to clear and convert forest if I accepted that oil palm plantations are five times more profitable than natural forests managed for timber and non-timber forest products. When I reluctantly agreed, she clarified that oil palm is not five times more profitable, it's fifty times more profitable. While this claim is a bit hyperbolic, the point hit home and I realized that my vision of a forested Borneo was unrealistic (for a somewhat similar scenario in Guyana, see Bulkan and Palmer 2016).

I should also clarify that I approached forest conservation in Borneo as might be expected for a forest ecologist/silviculturalist, first as a student and then as a faculty member of a large research university in the U.S.A. My approach is undoubtedly biased by my status as a white, male, American, liberal, and now old environmentalist. My modus operandi is captured in the phrase "if all you have is a hammer (research) everything looks like a nail (researchable issue)." Perhaps worse yet, my Science is reductionist, whereas forest and forestry systems are complex and not readily partitioned into the testable hypotheses I prefer (e.g., Filotas et al. 2014).

\section{Endorsement of the long discredited "information deficit" model for behavioral change}

A basic reason why my efforts and those of many other scientists failed to improve the fates of forests in Borneo was our collective belief that the data we provided would influence decisions and change behaviors. We showed, for example, that timber yields could be sustained only if harvest cycles were extended to 40-60 years and not the 25-30 years allowed by the government (e.g., Vanclay 1994; Sist et al. 1998). Equally disregarded was research that demonstrated the benefits of planned harvests by trained crews (e.g., Pinard and Putz 1996) and the acceleration of timber volume recovery after silvicultural treatments (e.g., Wadsworth and Zweede 2006). I should be embarrassed to admit that, although the "information deficit hypothesis" was discredited half a century ago (for an updated view, see Christiano and Neimand 2017), I naively expected the agents of forest destruction to mend their ways out of enlightened self-interest. I should have recognized that the likelihood that information will change behaviors is reduced further if it is not communicated to the right agents or is communicated in inappropriate ways by the wrong people (of whom, as a total outsider, I might be one). Had I been truly dedicated to conservation rather than research, instead of making one discovery, publishing it, and going on to the next, I would have focused on getting the recommended practices adopted. In my case, that would have meant no new research after 1993 when I first realized the climate change mitigation benefits of improved logging practices (Putz and Pinard 1993). Instead, I left the hard work of communication and implementation of my discoveries to extension agents, government officials, and representatives of "boundary" organizations (e.g., environmental groups; Lidskog 2014).

\section{Mistaken assumptions about shared values}

In my strategizing about conservation, I took to heart the results of willingness-to-pay and contingent valuation studies that reported that many people place high intrinsic value on nature in general and tropical forests in particular (e.g., Kramer and Mercer 1997). Unfortunately, despite these claims and increasing recognition of the many goods and services provided by natural ecosystems, the series of land-use decisions made by a variety of people over the past half-century resulted in the loss of much of the natural forest of Borneo.

Helping people recognize how nature's many values are compromised by decisions that promote economic development at nature's expense can be facilitated with graphical theory-of-change (ToC) models (e.g., Romero et al. 2017). These models identify the many interconnected agents that determine forest fates and specify the assumptions that underpin their behaviors. Well-developed ToCs can only emerge with input from a wide variety of stakeholders. Explicit recognition of the contextual and other factors that influence landuse decisions requires deep understanding of underlying philosophies and recognition of often subtle but consequential contextual factors. Useful ToCs generally include many agents, connections, and drivers that are often related in nonlinear ways and are affected by history, but even the most daunting model falls short of the complexity of reality. Unfortunately, many people continue to seek simple solutions to even complex problems.

I believe that my veneration of Bornean nature is shared more with the people native to that island than by colonists from more urbanized, developed, and crowded parts of Southeast Asia. To the extent that this assumption is true, restoration of the land rights to the indigenous peoples of Borneo will promote conservation while being ethically correct (e.g., Fa et al. 2020). Similarly, we need to harness the power of conservation-minded global consumers of palm oil and any of the other industrial products from onceforested Borneo by making clear the consequences of their consumption. 


\section{My failure to recognize forestry as a sunset industry}

While I resisted realization of the likely fate of much of Borneo's forests, the loggers knew. Over the past 40 years, their profits plummeted as timber yields declined and operating costs increased. The principal problem was that second entry logging yielded half as much commercial volume from smaller and lower quality trees of species with low market prices. Furthermore, as the accessible lowland forests were logged out and lost to agriculture and plantation forestry, loggers were relegated to steeper and otherwise more inhospitable terrain with much longer hauling distances. Over this same period, the number of timber concessions and processing mills in Borneo declined precipitously. These mill closures did not always result in net job losses because new jobs were created to process plantation products, both wood and palm oil. Downsizing of forest industries also did not impoverish the mill owners because they anticipated the closures, amortized their investments, and retrofitted their buildings for other uses. Some concession owners remained in the forestry business but exported their refurbished heavy equipment and harvesting crews to new logging frontiers in Papua New Guinea and Indonesia's Papuan Provinces as well as further afield to places like Liberia, Vanuatu, Gabon, and Guyana.

\section{Endorsed market incentives based on faulty market plans}

Since the early 1990s, I've tried to use market-based incentives to improve the fates of Bornean forests. I remain convinced of the potential for payments for ecosystem services (PES, including those for climate change mitigation through forest carbon sequestration) and still endorse voluntary third-party forest management certification (with some reservations; Romero and Putz 2018), but still wait for them to succeed at scale. One fundamental limitation of all such interventions is scarcity of funds: locals have seen little of the promised money for climate change mitigation (locally referred to as "sky money"), few, sporadic and small price premiums for certified timber, and little market differentiation between certified and non-certified forest products.

Given the opportunity costs of foregoing old growth logging and the often much larger ones of not converting logged-over forest into plantations, the necessary sums of money are often huge. I continue to expect tropical timber prices to increase in response to scarcity, but that hasn't happened, partially because legally harvested wood still has to compete with cheaper wood that is illegally sourced. Meanwhile, technological developments and changes in product preferences continue to promote substitutes for solid wood products, which further weakens the market. I still hope that governments will recognize the long-term environmental (and therefore economic) costs of logging old growth, especially on steep terrain, and prohibit exploitation of such areas. Making these changes in policies and practices before the old growth is gone will be difficult for both governments and forest industries that now rely on wood they did not grow. For logged-over areas, I advocate enhanced management that involves application of well-researched silvicultural treatments to increase timber yields, enhance carbon stocks, protect hydrological functions, and maintain biodiversity. In Borneo where governance failures are common, abandoned logging concessions typically suffer from illegal logging and outright forest clearance (e.g., Burivalova et al. 2020), which makes even intensified natural forest management the environmentally preferred land-use option.

Too many environmentalists, myself included, lack market savvy, and nearly everyone concerned about the fates of Bornean forests lacks the financial analyses on which market interventions should be based. It is clear, however, that in areas with uncontested land tenure and gentle topography within 12 hours travel time to an oil extraction facility, African oil palm is much more lucrative than forest management. This profit differential would decline with "green premiums" for certified wood and payments for additional carbon retained or sequestered by sound forest management, but on purely financial grounds, forest fates remain bleak (Ruslandi et al. 2017). It is not yet clear to what extent this income differential declines in more remote areas with contested tenure and adverse terrain where oil palm cultivation requires terracing. Under such conditions, which are unfavorable for intensive land management, natural forest management should be financially competitive. Unfortunately, I am unaware of the data needed to evaluate this option-for example, how rapidly do profits decline with slope angle? (Putz et al. 2018) Similarly, if the well-documented hydrological benefits of forest protection on steep slopes are included in the cost-benefit analyses, might not forest retention be fiscally prudent?

\section{Unjustified faith in the benefits of training and in connections between policy and practice}

My career was built on the assumption that logging will continue in the natural forests in Borneo, which means that reductions of its deleterious environmental impacts are important. The long-known rudiments of reduced-impact logging (RIL) include detailed planning of harvest operations and supervision of trained workers (e.g., Dykstra and Heinrich 1996). The well-researched benefits of RIL include faster recovery of timber and carbon stocks as well as better maintenance of biodiversity and hydrological functions. My undiminished faith in RIL is almost sad, given that the reasons RIL practices were not being applied 20 years ago (Putz et al. 2000) are still having their insidious effects today. This widespread failure to practice RIL was revealed by recent measurements of emissions from selective logging in Indonesia (Griscom et al. 2019) and six other tropical countries (Ellis et al. 2019); those field studies detected little evidence for RIL even in forests certified as responsibly managed by the Forest Stewardship Council (FSC).

Pantropical recognition by forestry experts of the many benefits of RIL motivated massive efforts in worker training over the past decades. Given that logging is among the world's most dangerous occupations (International Labour Organization 1998), investments in RIL training were motivated by concerns about social welfare as well as by the desire to decrease the deleterious environmental impacts of poor logging. The fundamental belief that justified investments in RIL training was that trained workers would apply what they learned (Fig. 1). Unfortunately, many of the assumptions upon which this simple theory-of-change depends are seldom supported. For example, although I lack hard data on the retention of trained workers in tropical logging concessions, turnover rates are known to be extremely high. I also 


\section{RIL- Requiring Policies Enacted

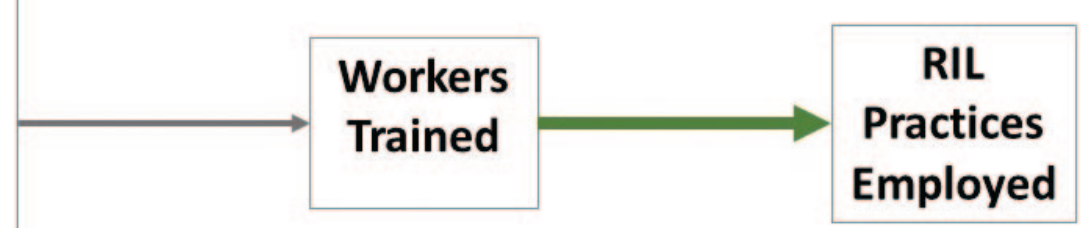

ASSUMPTIONS

1. Forest worker decisions and behaviors affect the fates of forests.

2. Training is of high quality.

3. Appropriate workers are trained.

4. Workers are capable of using RIL techniques.

5. Workers are motivated to use RIL techniques.

6. Trained workers are retained by the forest management enterprise (FME).

7. Appropriate monitoring protocols are effectively used by FMEs, certifiers, and government inspectors.

8. Critical decision-makers accept that RIL is more profitable.

Fig. 1 A simple theory-of-change (ToC) in which a governmental policy requires that trained forest workers employ RIL practices, which results in reductions in logging damage and carbon emissions, with subsequent increases in rates of timber volume recovery (not illustrated]. A few of the underlying assumptions of this $\mathrm{ToC}$ are listed.

admit to having only a vague idea about how RIL training could promote the desired behavioral change, such as not felling hollow trees. Despite these challenges, given what is at stake, on-going investments in RIL training are still needed but those efforts should be informed by insights from the behavioral sciences (e.g., Reddy et al. 2017).

Efforts to promote RIL through enactment of supporting legislation also apparently failed to change timber harvesting practices in Borneo. Even where the policies are supported by detailed implementing regulations, which was not the case in Kalimantan, enforcement remains difficult in remote areas where auditors are dependent upon the forest management enterprises they are charged to audit (Fig. 1). Risks of bias apply to both civil servants and client-paid auditors from certification bodies.

The fundamental reason why RIL practices are not readily adopted is that, despite the oft-repeated claim that increased efficiency renders them more profitable (e.g., Holmes et al. 2002), this assertion is not believed by the people who determine how forests are logged. Perhaps RIL researchers failed to communicate their results to the relevant actors. Unfortunately, the claim of overall cost-effectiveness of RIL is not always supported with data (Medjibe and Putz 2012). Furthermore, even if RIL financially benefits forest enterprise owners, it may not benefit critical forest workers along the production change. Given this uncertainty, and despite seeming like I'm falling back into the "information deficit" trap, I call for more and better studies that disaggregate the components of RIL and analyze their effectiveness from different perspectives. I suspect that this sort of analysis will reveal that at least some RIL practices should be adopted out of enlightened self-interest by some critical actors.

Concluding remarks - challenges of changing bad behaviors During my all-too-brief sojourn in British Columbia associated with the Doug Little Lecture, I visited managed and protected forests from Terrace to old growth east of Prince George. Despite the expertise of my guides, which they shared readily, it is likely that I misinterpreted much, but the parallels with my experience in Borneo seem clear. For example, I saw few industrial-scale applications of the close-tonature silviculture techniques about which I've read. These recommended practices differ radically from those appropriate for Borneo, but on that tropical mega-island it's similarly tough to wean forest industries from timber mining and other bad business practices. In both geographies, mining is likely to trump other land uses even when resources as valuable as orangutans and mountain caribou are at stake. Perhaps it surprised me most to learn that in British Columbia, as in my beloved Borneo, timber harvests continue in the increasingly rare and remote old-growth forests despite decreased profits. I wonder when the scarcity values of intact old-growth forest will be realized and these precious places will be preserved.

Naively and despite evidence to the contrary, I retain hope that the intrinsic value of nature will be realized by the people 
who determine the fates of forest in Borneo and elsewhere. My hopes were buoyed in B.C. by a walk amongst the giant western red cedars in the new Ancient Forest/Chun T'oh Whudujut Provincial Park. That marvelous stand of old growth reportedly was protected in large part due to the value that local people place on the sort of nature experience I enjoyed on a snowy November day. As forests becomes more remote and people become more urban, perhaps urbanites should be provided opportunities to hear the melodious duets of gibbons in majestic tropical forests or to witness grizzly bears foraging for salmon under ancient cedars. The goal is to grow biophilia and thereby increase political pressure to the point that the "hard decisions" about which our leaders lament become easy. Garnering nature-friendly sentiments and harnessing local political power recently worked for the Wehea Protected Forest in East Kalimantan, as it did for the Ancient Forest/Chun T'oh Whudujut Provincial Park, but both conservation successes required sustained and strategic efforts by diverse sets of stakeholders.

Forest conservation efforts should be informed by detailed theories-of-change that specify all the relevant agents and clarify the factors that influence the decisions and behaviors that determine forest fates. Most fundamentally, land-use policy-makers need to recognize that all management interventions, including protection, have a variety of consequences for a wide range of stakeholders. The natures of these direct and indirect tradeoffs and synergies should be made explicit in collaboratively constructed, locally tailored, and continuously improved theories-of-change. These models obviously need to incorporate consideration of the rapid pace of global climate change and any exacerbating influences of management interventions, such as the increased likelihood and severity of wildfires after heavy logging.

Given that attitudinal and then behavioral changes are needed if the current fates of forests are to be improved, it's obvious that more attention should be paid to insights from the behavioral sciences (e.g., Nilsson et al. 2019). Promoters of conservation need to recognize, and then use to their advantage, the apparent human preference for the status quo, their tendency to be motivated more by threatened losses than by potential gains, and the increased likelihoods of behavioral changes when such changes are socially endorsed (e.g., Cinner 2018).

Researchers need to expend more effort at seeking solutions rather than continuing to describe environmental problems in ever-increasing detail. With potential solutions in hand, the next challenge is to get the right messengers to communicate them in effective ways to the proper agents so as to elicit the desired attitudinal and behavioral changes.

It will not be easy to improve the fates of the increasingly scarce intact forests that remain in Borneo, British Columbia, and elsewhere in the world. The challenges are mostly not ecological/silvicultural and are complex, not just complicated, which means that multiple factors interact in often non-linear ways influenced by their histories and contexts. Global initiatives can help, but conservation successes almost invariably depend on local support. Data might also help, but most problems are probably not directly answerable with data. This claim notwithstanding, I will persist in my efforts to use Science to promote improved forest management. In any case, the first step is to admit the failures of previous interventions so as to avoid making the same mistakes again.

\section{Acknowledgments}

This essay was based on the Doug Little Memorial Lecture I presented at the University of Northern British Columbia in November 2019. While I gratefully acknowledge the efforts of my hosts to educate me about Canadian forestry, especially Phil Burton, Carla Burton, Oscar Venter, Michelle Venter, Darwyn Coxson, David Coates, and Erica Lillies, any erroneous connections and conclusions are my own. Much of what I know about Borneo was learned from teachers including Ruslandi, Hasbillah, Isna Marifa, Robert Ong, John Palmer, Lee Hua Seng, Bernie Chan, Juga anak Barieng, Richard Taumas, the late Art Klassen, Jan Falck, Francis Ng, Tang Hon Tat, and Paul Chai.

\section{References}

Bulkan, J. and J. Palmer. 2016. Global ecological signpost, local reality: The Moraballi Creek studies in Guyana and what happened afterwards. Forests 7: 317

Burivalova, Z., E.T. Game, B. Wahyudi, M. Ruslandi, E. Rifqi, S. MacDonald, S. Cushman, M. Voigt, S. Wich and D.S. Wilcove. 2020. Does biodiversity benefit when the logging stops? An analysis of conservation risks and opportunities in active versus inactive logging concessions in Borneo. Biol. Conserv. 241: 108369.

Christiano A. and A. Neimand. 2017. Stop raising awareness already. Stanford Social Innovation Review: https://ssir.org/articles/entry/stop_raising_awareness_already

Cinner, J. 2018. How behavioral science can help conservation. Science 362: 889-890.

Dykstra, D. P. and R. Heinrich. 1996. FAO Model Code of Forest Harvesting Practice. Food and Agricultural Organization, Rome.

Ellis, P.W., T. Gopalakrishna, R.C. Goodman, A. Roopsind, B. Griscom, P.M. Umunay, J. Zalman, E. Ellis, K. Mo, T.G. Gregoire and F.E. Putz. 2019. Climate-effective reduced-impact logging (RIL-C) can halve selective logging carbon emissions in tropical forests. Forest Ecol. Manag. 438: 255-260.

Fa, J.E., J.E.M. Watson, I. Leiper, P. Potapov, T.D. Evans, N.D. Burgess, Z. Molnár, Â. Fernández-Llamazares, T. Duncan, S. Wang, B.J. Austin H. Jonas, C.J. Robinson, P. Malmer, K.K. Zander, M.V. Jackson, E. Ellis, E.S. Brondizio and S.T. Garnett. 2020. Importance of Indigenous Peoples' lands for the conservation of Intact Forest Landscapes. Front. Ecol. Environ. doi:10.1002/fee.2148 Filotas, E., L. Parrott, P.J. Burton, R.L. Chazdon, K.D. Coates, L. Coll, S. Haeussler, K. Martin, S. Nocentini, K.J. Puettmann, F.E. Putz, S.W. Simard and C. Messier. 2014. Viewing forests through the lens of complex systems science. Ecosphere 5: 1-23.

Gaveau, D.L.A., B. Locatelli, M.A. Salim, H. Yaen, P. Pachec, and D. Sheil. 2018. Rise and fall of forest loss and industrial plantations in Borneo (2000-2017). Conserv. Lett. 2018; e12622. https://doi.org/ $10.1111 /$ conl.12622

Griscom, B.W., Z. Burivalova, P.W. Ellis, J. Halperin, D. Marthinus, R. Runting, B. Ruslandi, B. Wahyudi and F.E. Putz. 2019. Reduced-impact logging in Borneo to minimize carbon emissions while preserving sensitive habitats and maintaining timber yields. Forest Ecol. Manag. 438: 176-185.

Holmes, T.P., G.M. Blate, J.C. Zweede, R. Perrera Jr., P. Barretto, F. Boltz and R. Bauch. 2002. Financial and ecological indicators of reduced-impact logging performance in the eastern Amazon. Forest Ecol. Manag. 163: 93-110.

Hughes, A.C. 2018. Have Indo-Malaysian forests reached the end of the road? Biol. Cons. 223: 129-137.

International Labour Organization. 1998. Safety and Health in Forestry Work. ILO, Geneva, Switzerland.

Kramer, R.A. and D.E. Mercer. 1997. Valuing a global environmental good: U.S. residents' willingness to pay to protect tropical rain forests. Land Econ. 73: 196-210. 
Lidskog, R. 2014. Representing and regulating nature: Boundary organisations, portable representations, and the science-policy interface. Environ. Polit. 23: 670-687.

Medjibe, V.P. and F.E. Putz. 2012. Cost comparisons of reducedimpact and conventional logging in the tropics. J. Forest Econ. 18: 242-256.

Moro, J.C. 2019. Borneo Dammed: A Very Family Affair. Cypress Highlands Press, Florida.

Nilsson, D., K. Fielding and A.J. Dean. 2019. Achieving conservation impact by shifting focus from human attitudes to behaviors. Conserv. Biol. 34: 93-102.

Pinard, M.A. and F.E. Putz. 1996. Retaining forest biomass by reducing logging damage. Biotropica 28: 278-295.

Putz, F.E. 2018. Fates of forest in Borneo: a 40-year retrospective. Anthropology and Environment Society of the American Anthropological Association: wordpress.com/2018/07/31/fates-of-forestsin-borneo-a-40-year-retrospective https://aesengagement /.

Putz, F.E. and M. Pinard. 1993. Reduced-impact logging as a carbon-offset method. Conserv. Biol. 7: 755-757.

Putz, F.E., D.P. Dykstra and R. Heinrich. 2000. Why poor logging practices persist in the tropics. Conserv. Biol. 14: 951-956.

Putz, F.E., Ruslandi, P. Ellis and B. Griscom. 2018. Topographic restrictions on land-use practices: Consequences of different pixel sizes and data sources for natural forest management in the tropics. Forest Ecol. Manag. 422: 108-113.

Reddy, S.M.W., J. Montambault, Y.J. Masuda, E. Keenan, W. Butler, J.R.B. Fisher, S.T. Asah and A. Gneezy. 2017. Advancing conservation by understanding and influencing human behavior. Conserv. Lett. 10: 248-256.
Romero, C. and F.E. Putz. 2018. Theory-of-change development for evaluation of Forest Stewardship Council certification of sustained timber yields from natural forests in Indonesia. Forests 9, 547: doi:10.3390/f9090547.

Romero C., E.O. Sills, M.R. Guariguata, P.O. Cerutti, G.L. Lescuyer and F.E. Putz. 2017. Evaluation of the impacts of FSC certification on natural forest management in the tropics: A rigorous approach to assessment of a complex conservation intervention. Intern. For. Rev. 19: 1-14.

Ruslandi, C. Romero and F.E. Putz. 2017. Financial viability and carbon payment potential of large-scale silviculture intensification in logged dipterocarp forest in Indonesia. Forest Policy Econ. 85: 95-102.

Sist, P., T. Nolan, J.-G. Bertault and D. Dykstra. 1998. Harvest intensity versus sustainability in Indonesia. Forest Ecol. Manag. 108: 251-260.

Vanclay J.K. 1994. Sustainable timber harvesting: simulation studies in the tropical rainforests of north Queensland. Forest Ecol. Manag. 69: 299-320.

Wadsworth, F.H. and J.C. Zweede. 2006. Liberation: Acceptable production of tropical forest timber. Forest Ecol. Manag. 233: 45-51. 